Running head: NATIONAL IDENTITY AND OPPOSITION TO POLICIES

\title{
Conceptions of National Identity and Opposition to Bicultural Policies in New Zealand:
}

\section{A Comparison of Majority and Minority Perspectives}

\author{
Thierry Devos, ${ }^{1}$ Kumar Yogeeswaran, ${ }^{2}$ Petar Milojev, ${ }^{3}$ Chris G. Sibley ${ }^{3}$ \\ ${ }^{1}$ San Diego State University \\ ${ }^{2}$ University of Canterbury \\ ${ }^{3}$ University of Auckland
}

This is a postprint/accepted version of the manuscript. It is now published:

Devos, T., Yogeeswaran, K., Milojev, P., \& Sibley, C. (2020). Conceptions of national identity and opposition to bicultural policies in New Zealand: A comparison of majority and minority perspectives. International Journal of Intercultural Relations, 78, 33-

42. https://doi.org/10.1016/j.ijintrel.2020.04.004

Please cite the published version. The version available on PsyArXiv is before journal proof. The published version might be slightly different.

Correspondence concerning this article should be addressed to Thierry Devos, Department of Psychology, San Diego State University, 5500 Campanile Drive, San Diego, CA 921824611, USA. Email: tdevos@ @sdsu.edu. This research was supported by the Erskine Programme at the University of Canterbury, and by a grant from the Templeton Religion Trust (TRT0196). These funding sources did not play a role in the study design, the collection, analysis, and interpretation of data, the writing of the report, or the decision to submit this manuscript for publication. The authors declare that there is no conflict of interest. 


\begin{abstract}
Using a nationally representative sample, the present research tested whether conceptions of national identity differentially predicted attitudes toward bicultural policies among New Zealanders of European, Māori, Asian, and Pacific descent. A series of multi-group structural equation models revealed that among members of the majority group and all minority groups, endorsement of a civic conception of national identity (i.e., respecting political institutions and laws) was related to opposition to resource policies, but such a relationship was especially strong among the majority group. By contrast, endorsement of an ethnic conception of national identity (i.e., having Māori or European ancestry) was related to support for resource and symbolic policies among minority group members, but to opposition to the same policies among the majority group. The present work documents that belonging to a majority vs. minority group moderates the relations between conceptions of national identity (civic vs. ethnic) and support or opposition to specific bicultural policies. In addition, some elements of civic conceptions of national identity may legitimize inequalities rather than reduce them.
\end{abstract}

Keywords: national identity; biculturalism; policy; social status; majority vs. minority 


\section{Conceptions of National Identity and Opposition to Bicultural Policies in New Zealand:}

\section{A Comparison of Majority and Minority Perspectives}

Among pluralist societies, New Zealand stands out in that biculturalism is a deeply held component of its national identity. Embedded in the Treaty of Waitangi, signed in 1840, is the affirmation that people of Māori (indigenous) and non-Māori (mostly European) descent are equal partners in New Zealand national identity (Hayward, 2012). This principle is reflected in lay definitions of the national identity where people both implicitly and explicitly perceive Māori and Europeans as equally defining of New Zealand national identity (Sibley \& Liu, 2004, 2007; Sibley, Liu, \& Khan, 2010). Yet, it is also the case that support for bicultural policies in this country is mixed (Sibley \& Liu, 2004; Sibley, Robertson, \& Kirkwood, 2005). New Zealanders typically endorse symbolic representations of biculturalism, but they are not necessarily in favor of resource-based approaches to achieving biculturalism. The goal of the present research was to shed light on the opposition to bicultural policies by examining how resistance might be anchored in conceptions of national identity. On the surface, characteristics defining what it means to be a "true New Zealander" might not have direct implications for relations among the communities making up the population of this country, but these characteristics may nonetheless be linked to either opposition or support for bicultural policies. To document the role of conceptions of national identity, we examined whether their relations to attitudes toward bicultural policies differed as a function of respondents' ancestry (i.e., European, Māori, Pacific, or Asian descent) using a nationally representative sample. 


\section{Nuancing the Role of Civic vs. Ethnic Conceptions of National Identity}

Lay definitions of national identities outline criteria to be granted membership in the nation (Huynh, Devos, \& Altman, 2015; Theiss-Morse, 2009). The defining characteristics of nationhood not only highlight potential differences among countries; they also inform relations among subgroups making up the country's population. In pluralist societies, conceptions of national identity are intertwined with ethnic relations (Sidanius \& Petrocik, 2001). A vast literature in the social sciences draw a distinction between civic and ethnic conceptions of national identity (Bloemraad, Korteweg, \& Yurdakul, 2008; Pehrson \& Green, 2010; Schildkraut, 2007, 2011; Wright, Citrin, \& Wand, 2012; Yogeeswaran \& Dasgupta, 2014). When the defining features of the national identity reflect the endorsement of civic values and political participation, the implication is that all individuals, irrespective of their ethnic or cultural background, are included in the national identity so long as they live up to civic values and respect the country's laws (Pehrson \& Green, 2010; Yogeeswaran \& Dasgupta, 2014). In that sense, civic conceptions of national identity tend to attenuate status and power hierarchies between ethnic groups. In contrast, ethnic definitions of national identities are based on the notion that some fractions of the population, by virtue of their ancestry or characteristics linked to them, are more authentic members of the national identity and, as such, imply that groups deviating from the prototypical definition are secondrank citizens (Pehrson \& Green, 2010; Yogeeswaran \& Dasgupta, 2014). Clearly, ethnic conceptions of national identity entail exclusionary elements that perpetuate status and power hierarchies between ethnic groups. There is solid empirical evidence for the notion that negative attitudes toward ethnic minorities are linked to ethnic rather than civic conceptions of national identity (Doucerain, Amiot, Thomas, \& Louis, 2018; Meeus, Duriez, Vanbeselaere, \& Boen, 2010; Mukherjee, Molina, \& Adams, 2012; Pehrson, Brown, \& 
Zagefka, 2009; Pehrson, Vignoles, \& Brown, 2009; Sumino, 2017; Yogeeswaran et al., 2019).

The heuristic value of this distinction is undeniable and it has been shown to map on important aspects of national identity in New Zealand (Sibley, Hoverd, \& Liu, 2011; Yogeeswaran et al., 2019). At the same time, it might be worth nuancing this framework to reveal more complex relations (Bonikowski \& DiMaggio, 2016; Janmaat, 2006; Tamir, 2019). In particular, the inclusivity of a civic conception of national identity may be overstated in that some of its elements could be related to anti-minority sentiments, at least under certain circumstances. Research on symbolic racism has documented that the endorsement of individualistic values, such a self-reliance, hard work, and independence, coupled with lingering negative feelings toward ethnic minorities, accounts for opposition to policies aimed at making equality a reality (Sears \& Henry, 2005; Sears, Henry, \& Kosterman, 2000; Sears, van Laar, Carillo, \& Kosterman, 1997). Similarly, research shows that an ideology of colorblindness can be utilized to legitimize or reduce inequalities (Levy West, \& Ramirez, 2005; Knowles, Lowery, Hogan, \& Chow, 2009). This can occur because a colorblind ideology can be used to disregard structural inequities by asserting that everyone is the same and the system offers the same chances and opportunities to everyone (for a review, see Dovidio, Gaertner, \& Saguy, 2015). For example, endorsement of colorblind ideology predicts increased opposition to bicultural policies that redress inequalities between majority group members and indigenous minority populations (Yogeeswaran, Verkuyten, Osborne, \& Sibley, 2018).

One may extrapolate that civic conceptions of national identity can operate similarly. The affirmation of an abstract principle of national character based on respect of political institutions and laws can entail the notion that policies addressing systemic group-based 
inequities are no longer needed. From this vantage point, institutions and laws protect everyone and, thus, policies should be blind to the ethnic or cultural background of citizens. In fact, opposition to policies framed as providing material or symbolic support based on ethnicity or ancestry could be anchored in this very idea. Here also, the apparent neutrality of the abstract principle would occult structural disadvantages and preclude support for groupconscious policies construed as violating civic principles. Opposition to bilingual education in the U.S. at least partially stems from a similar logic (Huddy \& Sears, 1995; Sears \& Huddy, 1993).

The role of ancestry, a key element of ethnic conceptions of national identity, may also be more complex than what typically transpires from past research (e.g., Doucerain et al., 2018; Meeus et al., 2010; Mukherjee et al., 2012). In New Zealand, references to ancestry as a founding principle of nationhood typically affirms the rights of both indigenous (Māori) people and settlers (initially, European immigrants, Sibley et al., 2010, 2011). However, subscribing to ancestry as a building block of the national character does not necessarily translate into support for policies that honor or protect these rights, provide access to economic or social resources, or ensure political representation. In fact, following the logic outlined for civic conceptions of national identity, the affirmation of biculturalism as a core component of nationhood may imply that efforts to attenuate inequities and to level the playing field are not needed given that this very principle is encapsulated in the definition of what it means to be a New Zealander.

\section{Conceptions of National Identity and Hierarchy-Enhancing vs. -Attenuating Responses}

One of the hallmarks of abstract principles is that their meaning is malleable. Notions such as "respecting institutions and laws" or "ancestry" are polysemic; they can be construed 
to reflect one's own perspectives or interests. Depending on what conceptions of national identity come to signify, they can be linked either to opposition or support for concrete actions or policies (Sibley, 2013; Sindic, 2011; Sindic \& Reicher, 2008). A large body of research indicates that one of the driving forces behind political attitudes is group interests (Huddy, 2013; Lowery, Unzueta, Knowles, \& Goff, 2006): individuals tend to endorse positions that benefit the social groups or categories they belong to. Thus, depending on their insertions in a societal system, individuals may oppose policies undermining the economic or symbolic resources of their group, while others may support these policies on the ground that their group benefits from them. According to social dominance theory (Pratto, Sidanius, $\&$ Levin, 2006; Sidanius \& Pratto, 1999), members of dominant groups tend to exhibit hierarchy-enhancing cognitive, affective, or behavioral responses, whereas members of subordinate groups are more susceptible to display hierarchy-attenuating responses.

In New Zealand, bicultural policies can take the form of measures promoting Māori through resource distributions or symbolic incorporation in the country's culture (Sibley \& Liu, 2004). Examples of bicultural policies tied to resource distributions include granting ownership of the seabed and foreshore to Māori people, reserving places in medicine for Māori students, or providing tax exemptions on Māori land. Examples of bicultural policies reflecting inclusion at a more symbolic level include teaching Māori language at schools, incorporating Māori perspectives within schools, workplaces, and government operations, or singing the national anthem in Māori and English. Symbolic policies are typically supported by the majority of the population, but support for resource policies is more ambivalent (Newton, Sibley, \& Osborne, 2018; Sibley et al., 2005, 2010; Sibley \& Osborne, 2016). Not only can we expect that majority (i.e., European descent) and minority (i.e., Māori descent) 
individuals differ in their level of support for bicultural (resource or symbolic) policies, their policy stands may be differentially related to their conceptions of national identity.

Previous research based on social dominance theory has documented differences between majority and minority groups in attitudes towards or identifications with national identity (Sidanius, Feshbach, Levin, \& Pratto, 1997; Sidanius \& Petrocik, 2001; Staerklé, Sidanius, Green, \& Molina, 2010). In the present context, we examined whether majority and minority groups differed in terms of the relations between conceptions of national identity and opposition or support for bicultural policies. From a majority perspective, the affirmation of a civic conception of national identity, such as respecting the country's institutions and laws, could be construed as a guarantee that the rights and opportunities of all are upheld and, thus, would be seen as in contradiction with policies selectively protecting Māori people. In the same vein, affirming an ethnic conception of national identity, based on the inclusion of both Māori and European ancestry, may not warrant support for policies perceived as benefitting one of these groups (Māori people) over the other (people of European descent). In contrast, from a minority perspective, civic and ethnic conceptions of national identity could be viewed as the very reasons that the resources and symbolic incorporation of Māori people ought to be protected by social policies. Without these policies, biculturalism would remain an abstract principle that is not aligned with enduring economic and cultural inequities. In sum, civic and ethnic conceptions of national identity may have very different ramifications for bicultural policies depending on one's social positioning. 


\section{Research Overview}

Using a nationally representative sample, the goal of the present research was to test whether civic and ethnic conceptions of national identity differentially predict support or opposition for bicultural policies among New Zealanders of European, Māori, Asian, and Pacific descent. We focused on relatively specific aspects of conceptions of national identity. The civic conception of national identity was operationalized as respecting political institutions and laws (Devos \& Banaji, 2005; Reeskens \& Wright, 2011). The ethnic conception of national identity was operationalized as having Māori or European ancestry, an element specific to the New Zealand context (Sibley et al., 2011; Yogeeswaran et al., 2019). Although these operationalizations do not encompass other elements typically linked to the contrast between civic vs. ethnic conceptions of national identity (Bloemraad et al., 2008; Pehrson \& Green, 2010; Schildkraut, 2007, 2011; Wright et al., 2012; Yogeeswaran \& Dasgupta, 2014), they do provide insight into the role of an important component of civic and ethnic national identity on opposition to social policies. In line with previous research, bicultural policies were distinguished according to whether they focused on protecting resources for Māori people (resource policies) or ensured that the Māori heritage is incorporated into New Zealand national identity (symbolic policies). We expected that the relations between conceptions of national identity and attitudes toward bicultural policies protecting the resources of Māori people or ensuring that Māori people are incorporated into New Zealand national identity would differ as a function of respondent's majority vs. minority status. In addition to comparing these relations for respondents of European (majority) and Māori (minority) descent, we also examined these relations for respondents of Asian and Pacific descent. In their cases, predictions were less straightforward. Using more or less restrictive models (see Results section), we will determine whether a contrast between 
the majority group (New Zealanders of European descent) and all minority groups (New Zealanders of Māori, Asian, and Pacific descents) better fit the data or whether the data point to finer distinctions among minority groups.

The general proposition that the relations between conceptions of national identity and attitudes towards about bicultural policies are moderated by membership in a majority vs. minority group led to the formulation of four specific hypotheses. First, we hypothesized that endorsement of a civic conception of national identity would be more strongly linked to opposition to resource (Hypothesis 1) and symbolic (Hypothesis 2) policies among respondents belonging to the majority group rather than to minority groups. In addition, we expected that the endorsement of an ethnic conception of national identity would be more strongly linked to support for resource (Hypothesis 3) and symbolic (Hypothesis 4) policies among respondents belonging to minority groups rather than to the majority group.

\section{Method}

\section{Participants}

We analyzed data from Time 7 (2015) of the New Zealand Attitudes and Values Study (NZAVS), a 20-year longitudinal survey based on a national probability sample of New Zealand adults. Participants in the survey are sampled from the New Zealand electoral roll, which represents all citizens and permanent residents over 18 years of age as voter registration is compulsory (for full details on the sampling procedure, see Sibley, 2019). Analyses here reported are based on $n=12,382$ total participants (NZ European $n=10,153$; Māori $n=1,479$; Pacific $n=304$; Asian $n=446$ ) who responded to the Time 7 (2015) NZAVS. Of the total sample, $63.2 \%$ were female, $42.2 \%$ identified as religious, $75.7 \%$ reported having children, $75.5 \%$ reported being in a relationship, $77.9 \%$ reported being in 
some kind of employment, and $66.2 \%$ lived in an urban (vs. rural) area. Overall, the mean age of the sample was $50.71(S D=13.67)$ years. In terms of socioeconomic status, the New Zealand Deprivation index is a decile based measure of deprivation in neighborhood units across the country with 1 representing the most affluent neighborhoods and 10 representing the most deprived (for more details, see Salmond \& Crampton, 2012; Salmond, Crampton, \& Atkinson, 2007). The average score on the NZ Deprivation index in the present sample was $4.65(S D=2.76)$.

\section{Measures}

Resource Policy Opposition. Opposition to resource policies favoring Māori was assessed by four items taken from previous work (Liu \& Sibley, 2006; Sibley \& Liu, 2004; Yogeeswaran et al., 2018) rated on a 1 (Extremely Oppose) to 7 (Extremely Support) scale ( $\alpha$ $=.83$ ). The items in question included: "Māori ownership of the seabed and foreshore." (reverse scored); "Reserving places for Māori students to study medicine.” (reverse scored); "Rates exemption on Māori land." (reverse scored); and "Crown (government) ownership of the seabed and foreshore."

Symbolic Policy Opposition. Opposition to symbolic policies integrating Māori was assessed in a similar fashion, using four items taken from previous work (Liu \& Sibley, 2006; Sibley \& Liu, 2004; Yogeeswaran et al., 2018) rated on a 1 (Extremely Oppose) to 7 (Extremely Support) scale $(\alpha=.78)$. The items in question included: "Performance of the Haka at international sporting events." (reverse scored); "Waitangi day as a national celebration of biculturalism.” (reverse scored); “Teaching Māori language in New Zealand primary schools." (reverse scored); and "Singing the national anthem in Māori and English." (reverse scored). 
Although the measures of opposition to resource and symbolic policies could be associated with perceived economic and symbolic threats, respectively, the items do not include a clear reference to a sense of threat. Thus, in line with past research relying on these measures (Liu \& Sibley, 2006; Sibley \& Liu, 2004; Yogeeswaran et al., 2018), we deemed appropriate to conceptualize these measures as opposition to specific policies that protect resources for Māori people or symbolically incorporate Māori culture within the nation.

Conceptions of National Identity. The two key predictor variables assessed the importance of various qualities to the perception of New Zealand national identity similar to previous research (e.g., Reeskens \& Wright, 2011; Sibley et al., 2011). Specifically, the items were presented with the following stem: "How important do you personally think the following qualities are for being a 'true' New Zealander?"; and rated on a 1 (Not at All Important) to 7 (Very Important) scale. The two qualities in question were "To respect New Zealand's political institutions and laws." (Civic conception of national identity) and "to have Māori or European ancestry.” (Ethnic conception of national identity).

Demographic Information. In addition to these focal variables, the analyses presented here controlled for variation on a spectrum of relevant demographic variables including: gender (0 female, 1 male), age (years), NZDep 2006 (described above), whether or not one identified as religious ( 0 no, 1 yes), whether or not one had children ( 0 no, 1 yes), whether or not one was in a serious relationship ( 0 no, 1 yes), whether or not one was in payed employment ( 0 no, 1 yes), whether one lived in a rural or an urban area ( 0 rural, 1 urban), education, rank ordered using the New Zealand Qualifications Authority from 0 (no qualification) to 10 (doctoral degree, and the NZSEI 2006 - the New Zealand Socioeconomic index (see Milne, Byun, \& Lee, 2013). 


\section{Results}

\section{Analytic Strategy}

In order to assess the differential and simultaneous effects of conceptions of national identity on opposition to resource and symbolic policies for Māori, a multi-group structural equation modeling (SEM) framework was employed. The base model was estimated whereby the Resource Policy Opposition and Symbolic Policy Opposition were estimated as endogenous variables, with Civic and Ethnic Conceptions of National Identity as predictors of both. Moreover, the model included, and therefore adjusted for the standard set of demographics measured in each wave of the NZAVS, including gender, age, education, regional deprivation, SES, education, parental status, religion, and so forth. Adjusting for these demographics is standard practice in analyses of NZAVS data, including research predicting diverse outcomes such as vaccination attitudes (Lee, Duck, \& Sibley, 2017), modern racism (Satherley \& Sibley, 2018), attitudes toward abortion (Huang, Osborne, \& Sibley, 2019), and political party support (Greaves et al., 2017). The multi-group SEM framework allowed the simultaneous estimation of parameters across the four ethnic groups - NZ European, Māori, Pacific, and Asian.

Given the interest in both the effects of conceptions of national identity on bicultural policy opposition as well as group differences in these processes, we sequentially estimated a series of increasingly more constrained models. These were: (Model A) a fully saturated free model where all parameters were allowed to vary across the four groups; (Model B) a model where the effects of the demographic covariates were constrained to equality across the four groups; (Model C) a model where the constraints from Model B were retained in addition to constraining the residual variances of the two outcome variables to equality across all four 
groups; (Model D) a model retaining the restrictions from Model B and Model C, as well as constraining the focal effects (the effects of Civic and Ethnic Conceptions of National Identity on Resource and Symbolic Policy Opposition) to equality across the Pacific and Asian minority groups - leaving the effects for the NZ European and Māori groups freely estimated; and (Model E) a model retaining the constraints from Model B and Model C, but also constraining the focal effects to equality across all three of the NZ minority groups (Māori, Pacific, and Asian), in effect estimating the model for the NZ majority group (NZ Europeans) and the NZ minority groups. Applying these constraints allowed us to progressively compare model fit indices to ascertain the feasibility of a majority-minority model (Model E).

\section{Main Analyses}

Descriptive statistics and bivariate correlations for all of the variables used in the analyses, at the level of the overall sample, are presented in Table 1. Descriptive statistics and bivariate correlations for specific ethnic groups are available in the supplementary materials.

Model fit indices, including relative change in model fit for each progressively constrained model, are presented in Table 2. As Model A was fully saturated with all parameters freely estimated across all four groups, the model fit indices for this model are not informative. More importantly, as can be seen in Table 2, the model fit indices for Models B through E indicated good model fit for all models. The restriction of outcome residual variances across the four groups resulted in slight but appreciable decreases in model fit. However, the key model comparisons here were between the models incrementally restricting the four focal effects (Civic and Ethnic Conceptions of National Identity on 
Resource and Symbolic Policy Opposition) across the minority groups. Specifically, these are the comparisons between Model C and Model D and between Model D and Model E. As can be seen in Table 2, restricting the focal effects to equality across the Pacific and Asian minority groups (Model D) resulted in no appreciable changes to model fit relative to Model C. Further restricting the focal effects to equality across the three minority groups (Model E) also resulted in no appreciable changes to model fit relative to Model D. As such, Model E was used as the final estimated model, estimating the focal effects differentially for the NZ majority group (NZ European) relative to the minority groups (Māori, Pacific, and Asian).

The parameter estimates for the estimated model (Model E) are presented in Table 3 (the model fit indices for this model are presented in Table 2). The parameter estimates for Model A (the fully saturated model) are available in supplementary materials. In Model E, the predictors explained at least $10 \%$ of variance in Resource Policy Opposition $\left(r^{2}=.154\right.$ for European, .181 for Māori, .129 for Pacific, and .108 for Asian groups) and Symbolic Policy Opposition $\left(r^{2}=.145\right.$ for European, .146 for Māori, .135 for Pacific, and .101 for Asian groups). As can be seen in Table 3, differential effects of Civic and Ethnic Conceptions of National Identity on the Resource and Symbolic Policy Opposition can be observed across the majority group and the minority groups. For the majority group, Civic Conception of National Identity had a significant positive effect increasing Resource Policy Opposition, $b=.319$, se $=.013, \mathrm{z}=25.06, p<.001,95 \% \mathrm{CI}[.294, .344]$, but was not a significant predictor of Symbolic Policy Opposition, $b=-.003$, se $=.012, \mathrm{z}=-.25, p=.798$, $95 \%$ CI $[-.026, .020]$. On the other hand, among minority groups, Civic Conception of National Identity similarly had a significant positive effect predicting increases in Resource Policy Opposition, $b=.187$, se $=.022, \mathrm{z}=8.44, p<.001,95 \% \mathrm{CI}[.144, .231]$; however, as hypothesized (Hypothesis 1), this effect was significantly weaker than the corresponding 
effect in the majority group, $b_{\text {diff }}=.132$, se $=.025, \mathrm{z}=5.36, p<.001,95 \%$ CI $[.086, .186]$. Moreover, while the effect of Civic Conception of National Identity on Symbolic Policy Opposition was not significant in the majority group, the corresponding effect in the minority groups was significant and negative, predicting slightly lower levels of Symbolic Policy Opposition, $b=-.079$, se $=.020, \mathrm{z}=-3.88, p<.001,95 \% \mathrm{CI}[-.118,-.039]$. Here also, as expected (Hypothesis 2), the relations were significantly different for the NZ minority groups vs. the NZ majority group, $b_{\text {diff }}=.076$, se $=.023, \mathrm{z}=3.29, p=.001,95 \%$ CI $[.031, .122]$.

Looking again at Table 3, now at the relationship with Ethnic Conception of National Identity, a significant positive effect can be observed in the majority group, whereby Ethnic Conception of National Identity predicts higher levels of both Resource Policy Opposition, $b$ $=.018, \mathrm{se}=.007, \mathrm{z}=2.35, p=.019,95 \%$ CI [.003, .032], and Symbolic Policy Opposition, $b$ $=.034, \mathrm{se}=.007, \mathrm{z}=4.94, p<.001,95 \% \mathrm{CI}[.020, .047]$. Interestingly, among the minority groups, Ethnic Conception of National Identity had significant negative relationship, predicting decreases to both Resource Policy Opposition, $b=-.167$, se $=.014, \mathrm{z}=-12.01, p<$ $.001,95 \%$ CI [-.194, -.139], and Symbolic Policy Opposition, $b=-.064$, se $=.013, \mathrm{z}=-5.09$, $p<.001,95 \%$ CI [-.089, -.040]. As hypothesized, these effects were significantly different between the majority group and the minority groups, and notably stronger among the minority groups, $b_{\text {diff }}=.185, \mathrm{se}=.016, \mathrm{z}=12.02, p<.001,95 \% \mathrm{CI}[.156, .217]$ for the relationship between Ethnic Conception of National Identity and Resource Policy Opposition (Hypothesis 3); and $b_{\text {diff }}=.098, \mathrm{se}=.014, \mathrm{z}=7.12, p<.001,95 \%$ CI $[.073, .129]$ for the relationship between Ethnic Conception of National Identity and Symbolic Policy Opposition (Hypothesis 4). 


\section{Discussion}

The present research uses a nationally representative sample to examine how majority and minority group members' conceptions of national identity predict opposition to resource and symbolic policies that foster biculturalism, a defining characteristic of New Zealand that highlights a principle of equal partnership between people of Māori and European descent in the country. A series of multi-group SEM models reveal that among members of the majority group and all minority groups (Māori, Asians, and Pacific descendants), greater endorsement of civic national character as defining of $\mathrm{NZ}$ national identity predicts greater opposition to resource policies, but such a relationship is especially strong among majority group members. By contrast, endorsement of civic national character is not significantly related to attitudes toward symbolic policies among the majority group, and significantly related to support for symbolic policies among minority groups. The differences between resource vs. symbolic policies may be due to the fact that people are generally more accepting of symbolic policies to redress inequalities than resource-based policies (e.g., Sibley \& Liu, 2004; Sibley et al., 2005).

In contrast, defining NZ national identity in ethnic terms by highlighting the importance of European or Māori ancestry predicts opposition to resource and symbolic policies among the majority group, but support for resource and symbolic policies among minority groups. It may be that majority group members construe ancestry in a way that focused on their prototypical status in the country thereby ignoring other groups, or that they use Māori's prototypical status to imply that biculturalism has already been achieved in New Zealand and therefore policies are no longer necessary to support Māori people. By contrast, for NZ minorities, defining national identity in terms of Māori and European heritage 
predicts support for bicultural policies potentially because minority groups see New Zealand as failing to live up to its bicultural ideals and, thus, such policies remain necessary to do so.

\section{Theoretical Contributions}

The present work makes a novel contribution to the literature by examining how conceptions of national identity among both majority and minority groups account for support for or opposition to policies that redress inequalities between groups. While extant literature has focused on the implications of ethnic and civic national identity on attitudes, beliefs, and behaviors toward minority groups (for reviews, see Pehrson \& Green, 2010; Yogeeswaran \& Dasgupta, 2014), no work has examined whether the same national identity beliefs are differentially linked to opposition or support for policies that redress historical inequalities between groups among majority and minority groups. The present research provides a rare glimpse of how national identity beliefs have different meaning and implications for majority and minority groups. New Zealanders of European and Māori descent may endorse conceptions of national identity in a way that, at least partially, reflects a principle of group interest. Additionally, it is worth noting that New Zealanders of Asian and Pacific Island descent who are not directly impacted by bicultural policies show patterns of relations similar to Māori individuals, the indigenous group implicated in these bicultural policies. This may suggest that minority groups take on a similar perspective in recognizing inequities between majority and minority groups, possibly because they have a shared sense of minority identity. In the same vein, research by Craig and Richeson (2016) demonstrates that perceived discrimination increases coalitions among ethnic minority groups. Thus, it may be that individuals of Asian and Pacific descent ally with Māori people when recognizing their legitimate claim to national identity. 
Another important contribution of the present work is that, while past research has largely painted a neutral to positive picture on the effects of civic national identity on intergroup relations, findings reported here reveal that some elements of civic national character may operate similarly to other individualistic ideologies, such as colorblindness, in that they are linked to policy positions that may attenuate or legitimize inequalities between groups (e.g., Knowles et al., 2009; Yogeeswaran et al., 2018). Here, both majority and minority beliefs in NZ national identity as civic predict greater opposition to resource (but not symbolic) policies, suggesting that civic national character can indeed legitimize inequalities rather than reduce them.

An alternative interpretation of this finding is worth considering. The item used to measure the civic conception of national identity asks about the extent to which one perceives respect for New Zealand's political institutions and laws to be defining of a 'true' New Zealander. Such an item might be akin to an item measuring right-wing authoritarianism (Altemeyer, 1981, 1996). From this perspective, endorsement of right-wing authoritarianism might account for opposition to the redistribution of resources. To address this possibility, we re-ran all models with right-wing authoritarianism and social dominance orientation (Sidanius \& Pratto, 1999) -- another important predictor often considered simultaneously with right-wing authoritarianism (Duckitt \& Sibley, 2016). Opposition to resource policies was linked to right-wing authoritarianism, $b=.150$, se $=.012, \mathrm{z}=12.17, p$ $<.001,95 \% \mathrm{CI}[.130, .170]$ and to social dominance orientation, $b=.384, \mathrm{se}=.013, \mathrm{z}=$ $29.00, p<.001,95 \%$ CI $[.363, .406]$. However, even when these two predictors were included in the model, endorsement of a civic conception of national identity remained associated with opposition to resource policies among the majority group, $b=.296$, se $=$ $.012, \mathrm{z}=24.22, p<.001,95 \% \mathrm{CI}[.276, .316]$, and, to a lesser extent, among minority 
groups, $b=.185$, se $=.021, \mathrm{z}=8.71, p<.001,95 \% \mathrm{CI}[.150, .220]$. Thus, the relation between civic conception of national identity and opposition to resource distribution cannot be reduced to a broader endorsement of right-wing authoritarianism or social dominance orientation.

\section{Limitations and Future Directions}

While the present work has numerous strengths in that it utilizes a large nationally representative sample and examines the relationship between conceptions of national identity and policy attitudes using both majority and minority group perspectives, it has limitations that can be better addressed in future work. For starters, data are entirely correlational making it impossible to assess directionality. Additionally, the use of a single wave of data makes it difficult to test any underlying processes that drive the differential reactions between majority and minority groups in opposition or support for resource and symbolic policies as a function of civic vs. ethnic national character. This raises the need for future work to identify and test specific psycho-social processes that may be underlying the complex relations documented here. Future research would also benefit from relying on a more thorough assessment of conceptions of national identity that would include multiple items for both civic and ethnic conceptions of national identity. In addition, despite the fact that biculturalism is part of the founding of New Zealand, it might be useful to develop items that assess separately the associations between Māori and European ancestry with the NZ national identity (instead of the single-item used here).

Future work would also benefit from expanding the scope of the current findings to other national contexts as it is unclear if national identity conceptions similarly predict opposition to social policies that redress inequalities between majority and minority groups 
outside of NZ, or if some of these effects are specific to the NZ national context. The present work provides a starting point for future research examining group-based differences in how national identity conceptions relate to attitudes toward social policies. 


\section{References}

Altemeyer, B. (1981). Right-wing authoritarianism. Winnipeg, Manitoba, Canada: University of Manitoba Press.

Altemeyer, B. (1996). The authoritarian specter. Cambridge, MA: Harvard University Press.

Bloemradd, I., Korteweg, A., \& Yurdakul, G. (2008). Citizenship and immigration: Multiculturalism, assimilation, and challenges to the nation-state. Annual Review of Sociology, 34, 153-179. doi:10.1146/annurev.soc.34.040507.134608

Bonikowski, B., \& DiMaggio, P. (2016). Varieties of American popular nationalism. American Sociological Review, 81, 949-980. doi:10.1177/0003122416663683

Craig, M., \& Richeson, J. (2016). Stigma-based solidarity: Understanding the psychological foundations of conflict and coalition among members of different stigmatized groups. Current Directions in Psychological Science, 25, 21-27. doi:10.1177/0963721415611252

Devos, T., \& Banaji, M. (2005). American = white? Journal of Personality and Social Psychology, 88, 447-466. doi:10.1037/0022-3514.88.3.447

Dovidio, J. F., Gaertner, S. L., \& Saguy, T. (2015). Colorblindness and commonality: Included but invisible? American Behavioral Scientist, 59, 1518-1538. doi:10.1177/0002764215580591

Doucerain, M. M., Amiot, C. E., Thomas, E. F., \& Louis, W. R. (2018). What it means to be American: Identity inclusiveness/exclusiveness and support for policies about muslims among US-born whites. Analyses of Social Issues and Public Policy (ASAP). doi:10.1111/asap.12167

Duckitt, J., \& Sibley, C. J. (2016). The dual process motivational model of ideology and prejudice. In C. G. Sibley \& F. K. Barlow (Eds.), Cambridge handbook of the psychology of prejudice (pp. 188-221). Cambridge, UK: Cambridge University Press.

Greaves, L. M., Robertson, A., Cowie, L. J., Osborne, D., Houkamau, C. A., \& Sibley, C. G. (2017). Predicting party vote sentiment: Identifying the demographic and psychological correlates of party preference in two large datasets. New Zealand Journal of Psychology, 46, 164-175.

Hayward, J. (2012). Biculturalism. Te Ara - Encyclopedia of New Zealand. Retrieved from: http://www.TeAra.govt.nz/en/biculturalism

Huang, Y., Osborne, D., \& Sibley, C. G. (2019). Sociodemographic factors associated with attitudes toward abortion in New Zealand. New Zealand Medical Journal, 132, 9-20.

Huddy, L. (2013). From group identity to political cohesion and commitment. In L. Huddy, D. O. Sears, \& J. S. Levy (Eds.), The Oxford handbook of political psychology., 2nd ed. (pp. 737-773). New York, NY: Oxford University Press.

Huddy, L., \& Sears, D. O. (1995). Opposition to bilingual education: Prejudice or the defense of realistic interests? Social Psychology Quarterly, 58, 133-143. 
Huynh, Q. L., Devos, T., \& Altman, H. R. (2015). Boundaries of American identity: Relations between ethnic group prototypicality and policy attitudes. Political Psychology, 36, 449-468. doi:10.1111/pops.12189

Janmaat, J. G. (2006). Popular conceptions of nationhood in old and new European member states: Partial support for the ethnic-civic framework. Ethnic and Racial Studies, 29(1), 50-78. doi:10.1080/01419870500352363

Knowles, E., Lowery, B., Hogan, C., \& Chow, R. (2009). On the malleability of ideology: Motivated construals of colorblindness. Journal of Personality and Social Psychology, 96, 857-869. doi:10.1037/a0013595

Lee, C. H. J., Duck, I. M., \& Sibley, C. G. (2017). Demographic and personality correlates of vaccination attitudes in New Zealand. Vaccine, 35, 6089-6095. doi: 10.1016/j.vaccine.2017.09.061

Levy, S. R., West, T. L., \& Ramirez, L. (2005). Lay theories and intergroup relations: A social-developmental perspective. European Review of Social Psychology, 16, 189220.

Liu, J. H., \& Sibley, C. G. (2006). Differential effects of societal anchoring and attitude certainty in determining support or opposition to (bi)cultural diversity in New Zealand. Papers on Social Representations, 15, 1-15.

Lowery, B. S., Unzueta, M. M., Knowles, E. D., \& Goff, P. A. (2006). Concern for the ingroup and opposition to affirmative action. Journal of Personality and Social Psychology, 90, 961-974. doi:10.1037/0022-3514.90.6.961

Meeus, J., Duriez, B., Vanbeselaere, N., \& Boen, F. (2010). The role of national identity representation in the relation between in-group identification and out-group derogation: Ethnic versus civic representation. British Journal of Social Psychology, 49, 305-320. doi:10.1348/014466609X451455

Milne, B. J., Byun, U., \& Lee, A. (2013). New Zealand socio-economic index 2006. Wellington: Statistics New Zealand.

Mukherjee, S., Molina, L. E., \& Adams, G. (2012). National identity and immigration policy: Concern for legality or ethnocentric exclusion? Analyses of Social Issues and Public Policy (ASAP), 12, 21-32. doi:10.1111/j.1530-2415.2011.01257.x

Newton, H. J., Sibley, C. G., \& Osborne, D. (2018). The predictive power of post-colonial ideologies: Historical Negation and Symbolic Exclusion undermine support for resource-based bicultural policies. International Journal of Intercultural Relations, 62, 23-33. doi:10.1016/j.ijintrel.2017.03.005

Pehrson, S., Brown, R., \& Zagefka, H. (2009). When does national identification lead to the rejection of immigrants? Cross-sectional and longitudinal evidence for the role of essentialist in-group definitions. British Journal of Social Psychology, 48, 61-76.

Pehrson, S., \& Green, E. G. T. (2010). Who we are and who can join us: National identity content and entry criteria for new immigrants. Journal of Social Issues, 66, 695-716. doi:10.1111/j.1540-4560.2010.01671.x

Pehrson, S., Vignoles, V. L., \& Brown, R. (2009). National identification and anti-immigrant prejudice: Individual and contextual effects of national definitions. Social Psychology Quarterly, 72, 24-38. 
Pratto, F., Sidanius, J., \& Levin, S. (2006). Social dominance theory and the dynamics of intergroup relations: Taking stock and looking forward. European Review of Social Psychology, 17, 271-320.

Reeskens, T., \& Wright, M. (2011). Subjective well-being an national satisfaction: Taking seriously the "proud of what" question. Psychological Science, 22, 1460-1462. DOI:10.1177/0956797611419673

Salmond, C., \& Crampton, P, (2012). Development of New Zealand's deprivation index (NZDep) and its uptake as a national policy tool. Canadian Journal of Public Health, 103, 7-11.

Salmond, C., Crampton, P., \& Atkinson, J. (2007). NZDep2006 index of deprivation. Wellington. Department of Public Health, University of Otago Wellington.

Satherley, N., \& Sibley, C. G. (2018). The modern racism toward Māori scale. New Zealand Journal of Psychology, 47, 4-12.

Schildkraut, D. J. (2007). Defining American identity in the twenty-first century: How much 'there' is there? The Journal of Politics, 69, 597-615. doi:10.1111/j.14682508.2007.00562.x

Schildkraut, D. J. (2011). National identity in the United States. In S. J. Schwartz, K. Luyckx, \& V. L. Vignoles (Eds.), Handbook of identity theory and research (pp. 845-865). New York, NY US: Springer Science + Business Media.

Sears, D. O., \& Henry, P. J. (2005). Over thirty years later: A contemporary look at symbolic racism. Advances in Experimental Social Psychology, 37, 95-150.

Sears, D. O., Henry, P. J., \& Kosterman, R. (2000). Egalitarian values and contemporary racial politics. In D. O. Sears, J. Sidanius, \& L. Bobo (Eds.), Racialized politics: The debate about racism in America (pp. 75-117). Chicago: The University of Chicago Press.

Sears, D. O., \& Huddy, L. (1993). The symbolic politics of opposition to bilingual education. In S. Worchel \& J. A. Simpson (Eds.), Conflict between people and groups: Causes, processes, and resolutions (pp. 145-169). Chicago, US: Nelson-Hall.

Sears, D. O., van Laar, C., Carillo, M., \& Kosterman, R. (1997). The origins of white Americans opposition to race-targeted policies. Public Opinion Quarterly, 61, 16-53.

Sibley, C. G. (2013). Social dominance and representations of the national prototype: The exclusionary emphasis hypothesis of national character. International Journal of Intercultural Relations, 37, 212-224. doi:10.1016/j.ijintrel.2012.12.001

Sibley, C. G. (Updated 14 May 2019) Sampling procedure and sample details for the New Zealand Attitudes and Values Study. NZAVS Technical Documents, e01.

Sibley, C. G., Hoverd, W. J., \& Liu, J. H. (2011). Pluralistic and monocultural facets of New Zealand national character and identity. New Zealand Journal of Psychology, 40, 1929.

Sibley, C. G., \& Liu, J. H. (2004). Attitudes towards biculturalism in New Zealand: Social dominance and Pakeha attitudes towards the general principles and resource-specific aspects of bicultural policy. New Zealand Journal of Psychology, 33, 88-99. 
Sibley, C. G., \& Liu, J. H. (2007). New Zealand = bicultural? Implicit and explicit associations between ethnicity and nationhood in the New Zealand context. European Journal of Social Psychology, 37, 1222-1243. doi:10.1002/ejsp.459

Sibley, C. G., Liu, J. H., \& Khan, S. S. (2010). Implicit representations of ethnicity and nationhood in New Zealand: A function of symbolic or resource-specific policy attitudes? Analyses of Social Issues and Public Policy (ASAP), 10, 23-46. doi:10.1111/j.1530-2415.2009.01197.x

Sibley, C. G., \& Osborne, D. (2016). Ideology and post-colonial society. Political Psychology, 37(Suppl 1), 115-161. doi:10.1111/pops.12323

Sibley, C. G., Robertson, A., \& Kirkwood, S. (2005). Pakeha attitudes toward the symbolic and resource-specific aspects of bicultural policy in New Zealand: The legitimizing role of collective guilt for historical injustices. New Zealand Journal of Psychology, 34, 171-180.

Sidanius, J., Feshbach, S., Levin, S., \& Pratto, F. (1997). The interface between ethnic and national attachment: Ethnic pluralism or ethnic dominance? Public Opinion Quarterly, 61(1), 102-133. doi:10.1086/297789

Sidanius, J., \& Petrocik, J. R. (2001). Communal and national identity in a multiethnic state: A comparison of three perspectives. In R. D. Ashmore, L. Jussim, \& D. Wilder (Eds.), Social identity, intergroup conflict, and conflict resolution (pp. 101-129). Oxford, U.K.: Oxford University Press.

Sidanius, J., \& Pratto, F. (1999). Social dominance: An intergroup theory of social hierarchy and oppression. Cambridge, MA: Cambridge University Press.

Sindic, D. (2011). Psychological citizenship and national identity. Journal of Community \& Applied Social Psychology, 21, 202-214. doi:10.1002/casp.1093

Sindic, D., \& Reicher, S. D. (2008). The instrumental use of group prototypicality judgments. Journal of Experimental Social Psychology, 44, 1425-1435. doi:10.1016/j.jesp.2008.05.007

Staerklé, C., Sidanius, J., Green, E. G. T., \& Molina, L. E. (2010). Ethnic minority-majority asymmetry in national attitudes around the world: A multilevel analysis. Political Psychology, 31, 491-519. doi:10.1111/j.1467-9221.2010.00766.x

Sumino, T. (2017). National identity and public attitudes toward multiculturalism in Canada: Testing the indirect effect via perceived collective threat. Canadian Journal of Behavioural Science / Revue canadienne des sciences du comportement, 49, 183-194. doi:10.1037/cbs0000076

Tamir, Y. (2019). Not so civic: Is there a difference between ethnic and civic nationalism? Annual Review of Political Science, 22, 419-434. doi:10.1146/annurev-polisci022018-024059

Theiss-Morse, E. (2009). Who counts as an American? The boundaries of national identity. New York, NY: Cambridge.

Wright, M., Citrin, J., \& Wand, J. (2012). Alternative measures of American national identity: Implications for the civic-ethnic distinction. Political Psychology, 33, 469482. doi:10.1111/j.1467-9221.2012.00885.x 
Yogeeswaran, K., Afzali, M., Andrews, N., Chivers, E., Wang, M., Devos, T., \& Sibley, C. (2019). Exploring New Zealand national identity and its importance for attitudes toward Muslims and diversity. New Zealand Journal of Psychology, 48, 29-35.

Yogeeswaran, K., \& Dasgupta, N. (2014). Conceptions of national identity in a globalised world: Antecedents and consequences. European Review of Social Psychology, 25, 189-227. doi:10.1080/10463283.2014.972081

Yogeeswaran, K., Verkuyten, M., Osborne, D., \& Sibley, C. (2018). "I have a dream" of a colorblind nation? Examining the relationship between racial colorblindness, system justification, and support for policies that redress inequalities. Journal of Social Issues, 74, 282-298. doi:10.1111/josi.12269 
NATIONAL IDENTITY 27

Table 1. Bivariate correlations and descriptive statistic for the variable used in the analyses for the overall sample.

\begin{tabular}{|c|c|c|c|c|c|c|c|c|c|c|c|c|c|c|}
\hline & 1 & 2 & 3 & 4 & 5 & 6 & 7 & 8 & 9 & 10 & 11 & 12 & 13 & 14 \\
\hline \multicolumn{15}{|l|}{ 1. Resource Policy } \\
\hline 2. Symbolic Policy & $.531^{* *}$ & & & & & & & & & & & & & \\
\hline 3. Civic Conception & $.246^{* *}$ & $.022^{*}$ & & & & & & & & & & & & \\
\hline 4. Ethnic Conception & $-.052^{* *}$ & $.026^{* *}$ & $.023^{*}$ & & & & & & & & & & & \\
\hline 5. Gender & $.148^{* *}$ & $.252^{* *}$ & .000 & $-.025^{* *}$ & & & & & & & & & & \\
\hline 6. Age & $.143^{* *}$ & $.199^{* *}$ & $.170^{* *}$ & $.100^{* *}$ & $.121^{* *}$ & & & & & & & & & \\
\hline 7. NZDep & $-.132^{* *}$ & $-.034^{* *}$ & $-.063^{* *}$ & $.107^{* *}$ & $-.027^{* *}$ & $-.039^{* *}$ & & & & & & & & \\
\hline 8. Religious & $-.023^{* *}$ & $-.023^{*}$ & $.058^{* *}$ & $.102^{* *}$ & $-.052^{* *}$ & $.137^{* *}$ & $.069^{* *}$ & & & & & & & \\
\hline 9. Parent & $.059^{* *}$ & $.033^{* *}$ & $.105^{* *}$ & $.065^{* *}$ & .005 & $.401^{* *}$ & $-.056^{* *}$ & $.083^{* *}$ & & & & & & \\
\hline 10. Partner & $.086^{* *}$ & .014 & $.069^{* *}$ & $-.039^{* *}$ & $.068^{* *}$ & $.058^{* *}$ & $-.193^{* *}$ & -.007 & $.295^{* *}$ & & & & & \\
\hline 11. Employed & $-.020^{*}$ & $-.095^{* *}$ & $-.031^{* *}$ & $-.076^{* *}$ & $.040^{* *}$ & $-.313^{* *}$ & $-.050^{* *}$ & $-.081^{* *}$ & $-.079^{* *}$ & $.058^{* *}$ & & & & \\
\hline 12. Urban Area & $-.073^{* *}$ & $-.051^{* *}$ & -.011 & $-.082^{* *}$ & .007 & $-.099^{* *}$ & $-.145^{* *}$ & $-.025^{* *}$ & $-.121^{* *}$ & $-.059^{* *}$ & $.035^{* *}$ & & & \\
\hline 13. NZReg & $-.185^{* *}$ & $-.213^{* *}$ & $-.042^{* *}$ & $-.211^{* *}$ & $-.051^{* *}$ & $-.163^{* *}$ & $-.157^{* *}$ & $-.039^{* *}$ & $-.101^{* *}$ & $.042^{* *}$ & $.153^{* *}$ & $.145^{* *}$ & & \\
\hline 14. SEI & $-.124^{* *}$ & $-.169^{* *}$ & .001 & $-.149^{* *}$ & $-.064^{* *}$ & $-.060^{* *}$ & $-.171^{* *}$ & $-.023^{*}$ & -.011 & $.083^{* *}$ & $.123^{* *}$ & $.144^{* *}$ & $.573^{* *}$ & \\
\hline$M$ & 4.90 & 2.81 & 6.230 & 2.78 & .37 & 5.71 & 4.65 & .42 & .760 & .76 & .78 & .66 & 5.20 & 54.07 \\
\hline$S D$ & 1.54 & 1.32 & 1.090 & 1.87 & .48 & 13.67 & 2.76 & .49 & .430 & .43 & .42 & .47 & 2.77 & 15.27 \\
\hline
\end{tabular}

*. Correlation is significant at the .05 level (2-tailed). ${ }^{* *}$. Correlation is significant at the .01 level (2-tailed). 
Table 2. Model fit indices and model fit change for the incrementally restricted multi-group models. Note: Model A = Fully saturated/free model; Model B = Demographic covariates restricted to equality across groups; Model $\mathrm{C}=$ Demographic covariates and the residual variances of the dependent variables restricted to equality across groups; Model $D=$ Demographic covariates and the residual variances of the dependent variables restricted to equality across groups, in addition to the focal effects restricted to equality for Pacific and Asian groups; Model E = Demographic covariates and the residual variances of the dependent variables restricted to equality across groups, in addition to the focal effects restricted to equality for Māori, Pacific and Asian groups. ${ }^{*} p<.05 . \Delta$ indicates relative change in the respective index.

\begin{tabular}{lccccc} 
& Model A & Model B & Model C & Model D & Model E \\
\hline $\mathrm{X}^{2}$ & 0 & $280.593^{*}$ & $561.495^{*}$ & $564.867^{*}$ & $568.071^{*}$ \\
$\mathrm{df}$ & 0 & 60 & 69 & 73 & 77 \\
$\mathrm{RMSEA}$ & 0 & .034 & .048 & .047 & .045 \\
{$[95 \% \mathrm{CI}]$} & 0 & {$[.030, .039]$} & {$[.044, .052]$} & {$[.043, .050]$} & {$[.042, .049]$} \\
$\mathrm{CFI}$ & 1.000 & .970 & .932 & .932 & .932 \\
$\mathrm{TLI}$ & 1.000 & .949 & .902 & .907 & .912 \\
$\mathrm{sRMR}$ & 0 & .036 & .064 & .064 & .065 \\
$\mathrm{AIC}$ & 78011 & 78172 & 78434 & 78430 & 78425 \\
$\mathrm{aBIC}$ & 78503 & 78409 & 78634 & 78612 & 78591 \\
& & & & & \\
\hline$\Delta \mathrm{RMSEA}$ & & & .014 & -.001 & -.002 \\
$\Delta \mathrm{SRMR}$ & & & .028 & 0 & .001 \\
$\Delta \mathrm{CFI}$ & & & -.038 & 0 & 0 \\
$\Delta \mathrm{X}^{2}$ & & & $280.902^{*}$ & 3.372 & 3.204 \\
$\Delta \mathrm{df}$ & & & 9 & 4 & 4 \\
\hline
\end{tabular}

Note: While the restriction of demographic covariates and the residual variances of the dependent variables to equality across all four groups results in significant changes (decreases) in model fit, constraining the focal effects to equality across the three minority groups (Models $D$ and $E$ ) results in no appreciable changes in model fit. This suggests that, for this model, the three minority groups (Māori, Pacific, and Asian) may be compared as a single group relative to majority group (NZ European). 
Table 3. Model parameters (regression coefficients) from majority group (NZ European) vs. minority groups (NZ Māori, Pacific, \& Asian) model (Model E).

\begin{tabular}{|c|c|c|c|c|c|c|c|c|c|c|c|c|}
\hline & \multicolumn{6}{|c|}{ Majority Group (NZ European) } & \multicolumn{6}{|c|}{ Minority Groups (NZ Māori, Pacific, \& Asian) } \\
\hline & $\mathrm{b}$ & $-95 \% \mathrm{Cl}$ & $+95 \% \mathrm{Cl}$ & se & z & $p$ & $\mathrm{~b}$ & $-95 \% \mathrm{Cl}$ & $+95 \% \mathrm{Cl}$ & se & z & $p$ \\
\hline \multicolumn{13}{|c|}{ Resource Policy Opposition } \\
\hline Civic Conception & 0.319 & 0.294 & 0.344 & 0.013 & 25.058 & 0.000 & 0.187 & 0.144 & 0.231 & 0.022 & 8.439 & 0.000 \\
\hline Ethnic Conception & 0.018 & 0.003 & 0.032 & 0.007 & 2.348 & 0.019 & -0.167 & -0.194 & -0.139 & 0.014 & -12.014 & 0.000 \\
\hline Gender & 0.382 & 0.333 & 0.431 & 0.025 & 15.256 & 0.000 & 0.382 & 0.333 & 0.431 & 0.025 & 15.256 & 0.000 \\
\hline Age & 0.003 & 0.001 & 0.005 & 0.001 & 3.283 & 0.001 & 0.003 & 0.001 & 0.005 & 0.001 & 3.283 & 0.001 \\
\hline NZDep & -0.040 & -0.049 & -0.031 & 0.005 & -8.688 & 0.000 & -0.040 & -0.049 & -0.031 & 0.005 & -8.688 & 0.000 \\
\hline Religious & -0.014 & -0.063 & 0.034 & 0.025 & -0.585 & 0.559 & -0.014 & -0.063 & 0.034 & 0.025 & -0.585 & 0.559 \\
\hline Parent & -0.032 & -0.096 & 0.031 & 0.032 & -1.011 & 0.312 & -0.032 & -0.096 & 0.031 & 0.032 & -1.011 & 0.312 \\
\hline Partner & 0.113 & 0.055 & 0.172 & 0.030 & 3.805 & 0.000 & 0.113 & 0.055 & 0.172 & 0.030 & 3.805 & 0.000 \\
\hline Employed & 0.057 & -0.004 & 0.117 & 0.031 & 1.844 & 0.065 & 0.057 & -0.004 & 0.117 & 0.031 & 1.844 & 0.065 \\
\hline Urban Area & -0.202 & -0.253 & -0.151 & 0.026 & -7.747 & 0.000 & -0.202 & -0.253 & -0.151 & 0.026 & -7.747 & 0.000 \\
\hline NZReg & -0.103 & -0.114 & -0.093 & 0.005 & -19.121 & 0.000 & -0.103 & -0.114 & -0.093 & 0.005 & -19.121 & 0.000 \\
\hline SEI & -0.005 & -0.007 & -0.003 & 0.001 & -5.267 & 0.000 & -0.005 & -0.007 & -0.003 & 0.001 & -5.267 & 0.000 \\
\hline \multicolumn{13}{|c|}{ Symbolic Policy Opposition } \\
\hline Civic Conception & -0.003 & -0.026 & 0.020 & 0.012 & -0.255 & 0.798 & -0.079 & -0.118 & -0.039 & 0.020 & -3.882 & 0.000 \\
\hline Ethnic Conception & 0.034 & 0.02 & 0.047 & 0.007 & 4.937 & 0.000 & -0.064 & -0.089 & -0.04 & 0.013 & -5.089 & 0.000 \\
\hline Gender & 0.602 & 0.557 & 0.647 & 0.023 & 26.324 & 0.000 & 0.602 & 0.557 & 0.647 & 0.023 & 26.324 & 0.000 \\
\hline Age & 0.013 & 0.011 & 0.015 & 0.001 & 13.439 & 0.000 & 0.013 & 0.011 & 0.015 & 0.001 & 13.439 & 0.000 \\
\hline NZDep & -0.013 & -0.021 & -0.004 & 0.004 & -2.977 & 0.003 & -0.013 & -0.021 & -0.004 & 0.004 & -2.977 & 0.003 \\
\hline Religious & -0.065 & -0.109 & -0.021 & 0.023 & -2.874 & 0.004 & -0.065 & -0.109 & -0.021 & 0.023 & -2.874 & 0.004 \\
\hline Parent & -0.121 & -0.178 & -0.063 & 0.029 & -4.122 & 0.000 & -0.121 & -0.178 & -0.063 & 0.029 & -4.122 & 0.000 \\
\hline Partner & -0.004 & -0.058 & 0.049 & 0.027 & -0.164 & 0.870 & -0.004 & -0.058 & 0.049 & 0.027 & -0.164 & 0.870 \\
\hline Employed & -0.111 & -0.165 & -0.056 & 0.028 & -3.947 & 0.000 & -0.111 & -0.165 & -0.056 & 0.028 & -3.947 & 0.000 \\
\hline Urban Area & -0.070 & -0.117 & -0.024 & 0.024 & -2.955 & 0.003 & -0.070 & -0.117 & -0.024 & 0.024 & -2.955 & 0.003 \\
\hline NZReg & -0.077 & -0.087 & -0.068 & 0.005 & -15.699 & 0.000 & -0.077 & -0.087 & -0.068 & 0.005 & -15.699 & 0.000 \\
\hline SEI & -0.006 & -0.000 & -0.004 & 0.001 & -6.511 & 0.000 & -0.006 & -0.007 & -0.004 & 0.001 & -6.511 & 0.000 \\
\hline
\end{tabular}


